\title{
Regional innovation strategy for resilience and transformative industrial path development: evolutionary theoretical perspectives on innovation policy
}

\author{
Bjørn T. ASHEIM*, Sverre J. HERSTAD**
}

\begin{abstract}
Many countries in the developed world are currently experiencing low rates of economic growth, which is furthermore regionally and socially unequal. This increasing inequality seems to have deepened during the Corona crisis. When economic policies are discussed in these demanding times, the strategic question remains whether the best strategy is to seek to bounce back to the 'old normal', or to use this critical time as a conjuncture to departure on a development path to a 'new normal' that is more innovative, sustainable, and inclusive. In light of this, the main aim of this paper is to look for new perspectives on theory and policy with important implications for promoting the most radical forms of industrial path development, viz. path diversification based on unrelated knowledge combinations and new path creation, securing the adaptability of an economy to become more resilient.
\end{abstract}

Keywords: regional innovation policy, resilience, transformative path development, evolutionary theory

\section{Introduction}

Many countries in the developed world are currently experiencing low rates of economic growth, which is furthermore regionally and socially unequal. This increasing inequality seems to have deepened during the Corona crisis. When economic policies are discussed in these demanding times, the strategic question remains whether the best strategy is to seek to bounce back to the 'old normal', i.e.

\footnotetext{
* Bjørn T. ASHEIM is Professor at the University of Stavanger, Business School and Centre of Innovation Research, University of Stavanger, Stavanger, Norway; e-mail: bjorn.t.asheim@uis.no.

${ }^{* *}$ Sverre J. HERSTAD is Professor at the Department of Sociology and Human Geography, University of Oslo, Norway; and School of Business and Social Sciences, Inland Norway University of Applied Sciences; e-mail: s.j.herstad@ sosgeo.uio.no.
} 
to the situation we had before the outbreak of the Corona crisis, or to use this critical time as a conjuncture to departure on a development path to a 'new normal' that is more innovative, sustainable and inclusive, making sure that the technological and other changes that such a policy would require would not cause greater social and regional inequalities. As the Corona crisis can be seen in many ways as a forewarning of the coming climate crisis (many regions and countries are already experiencing disastrous consequences of extreme weather conditions), this provides compelling arguments that a push forward to a 'new normal' is the only viable strategy to secure a safer and more stable future.

A potential impact of the Corona crisis is to strengthen the legitimacy of governmental intervention and the role of the welfare state. Western and many emerging economies are now entirely dependent on massive state aid. Moreover, it looks as if the organisational and institutional framework of Nordic and Western European welfare states has been best equipped to handle the crisis with a welldeveloped health sector and robust mechanisms to secure the economic well-being of citizens. This might give the welfare state a competitive advantage to pursue the necessary 'mission-oriented' innovation policies required to combat the grand social challenges that lie ahead of us.

The aim of such mission-oriented policies is to build a more resilient society that is more innovative, socially and regionally inclusive and environmentally sustainable. Boschma (2015) provides an evolutionary based definition of (regional) resilience as to simultaneously secure adaptation and adaptability. Adaptation represents changes within preconceived paths, while adaptability concerns developing new paths, i.e. departing from existing paths. While adaptation fundamentally reproduces existing structures, adaptability represents transformative changes through breakthrough innovations and new industrial development. In contrast to an engineering-based concept of resilience, meaning back to the 'old normal', the evolutionary perspective focuses more on the long-term evolutions of regions and their ability to reconfigure their industrial, technological and institutional structures for a more resilient society. The evolutionary meaning of resilience implies both a more short-term perspective of how to secure adaptation of existing structures and the longer-term perspective of promoting transformative changes in the economy to contribute to solving grand societal challenges. Overcoming this trade-off which, in organisational theory, is known as the tension between exploration and exploitation (March 1991) is key for regions to become resilient.

The evolutionary perspective on regional resilience can be concretised by referring to the literature on new path development, which differentiates between path upgrading (climbing global value chains, renewal and niche development), path importation, path diversification (related and unrelated) and new path creation. According to Boschma, related diversification (and upgrading, our addition) secures adaptation, capturing (current) value creation potential, while unrelated 
diversification (and new path creation (our addition)), promoting (new) value creation potential, guarantees adaptability (Boschma, 2015).

Historically, innovation has been the most important source of increased productivity and value creation, and, thus, for making societies wealthier. Reflecting on this, there is strong agreement that innovation is the key factor in promoting economic restructuring, resilience and sustainable development. As expressed in the Lisbon strategy of the EU, innovation-based growth strategies were for long thought of as identical to 'horizontal' policies emphasizing general framework conditions and promoting R\&D and university-industry linkages in accordance with the linear view of innovation (Jensen et al., 2007; Bonaccorsi et al., 2009). Increasingly, a broader and more comprehensive view has evolved. It sees innovation as dependent on complex processes of interactive learning involving different types of knowledge (analytical, synthetic, symbolic) distributed among different types of actors (researchers, investors, managers, employees). In this perspective, technological advances through $\mathrm{R} \& \mathrm{D}$ is considered a necessary yet not sufficient condition as innovation-based development (Binz et al., 2016; Coenen et al., 2016; Mazzucato and Semieniuk, 2017) also depends on experience-based knowledge and specialized industrial capabilities built cumulatively by other means than university R\&D, e.g. through continuous experimentation in contexts of problem solving and application (Herstad et al., 2015). This underscores the need for different policy areas and initiatives to operate in tandem and form a holistic innovation policy able to mobilize actors on a broad basis and, in this way, create - through learning - the resources that industrial development is to build on.

In light of this, the main aim of this paper is to look for new perspectives on theory and policy with important implications for promoting the most radical forms of industrial path development, viz. path diversification based on unrelated knowledge combinations and new path creation securing the adaptability of an economy. Basically, this concerns expanding the access to diversity in knowledge exploration and exploitation sub-systems. We argue that there are two main routes to achieve this: by stimulating experimentation with (previously) unrelated knowledge combinations and by sourcing non-local knowledge. While the great and lasting achievements of evolutionary economic geography in terms of research on regional economic development and diversification must be acknowledged, with some exceptions, the potentials of unrelated knowledge combinations and non-local knowledge to create new development paths have not represented the main focus of its studies. Instead, the main contribution from evolutionary economic geography (EEG) has been to unravel theoretically and document empirically the importance of related variety for the ability of economies to self-transform from within by gradually diversifying into new activities that are closely related to existing ones (regional branching) (Boschma and Frenken, 2011; Frenken and Boschma, 2007).

Related variety and regional branching will normally represent the dominant paths to regional economic diversification in the short and medium term (Boschma, 
2017). However, the time might have come to broaden the scope to look for sources of more radical paths of diversification. The risk of lock-in grows with increasing specialization of the regional and national economy (cf. Grabher (1993, p. 256) trap of rigid specialisation). The more perfectly adapted the economy is, the less diversity of knowledge exploration and exploitation exists, and the weaker will its (marketbased) adaptability be. In turn, this increases the importance of non-market mechanisms (e.g. policy) to support the search and development of diversity in knowledge exploration and exploitation. This scenario accurately describes the reality of many developed economies. If a sustainable and resilient economic restructuring and diversification is to be achieved, the search for innovation and industrial policies to promote such a development has to extend beyond the perspectives of related variety and regional branching, i.e. gradual change based directly on current industrial capabilities.

The second section of this paper critically summarizes the baseline argumentation of evolutionary economic geography and the closely related 'product space' approach. We demonstrate how this argumentation provides support for the emerging, yet historically well-grounded 'new industrial policy' logic, as reflected in concepts such as 'smart specialization' (Foray, 2014a, b; Bonaccorsi et al., 2009; The Expert Group, 2006), and the 'entrepreneurial' (Mazzucato, 2013; 2016) or 'developmental' (Block, 2008; Wade, 2017) state. Based on this, the third section sketches out the building blocks for a theory of new path development through unrelated knowledge combinations and non-local knowledge, while the fourth discusses the related questions of policy logics and policy mixes. Finally, the conclusion emphasizes that policies seeking to promote radical innovation and new path creation involve intervention along three complementary dimensions, each of which contains numerous questions and issues that demand research and careful consideration in policy design:

1. Exploration: Policy guidance, logics, infrastructures and tools providing incentives for actors to explore combinations of (previously) unrelated knowledge.

2. Anchoring and exploitation: Policy guidance, logics, infrastructures and tools creating incentives for entrepreneurs (corporate as well as institutional or individual) to 'grow' new (unrelated) activities in the economy in spite of limited initial resource support (when they deviate from current specializations).

3. The creation of 'policy spaces' where failure is legitimate, and coordination (across levels of governance and policy fields) combined with monitoring based on dedicated infrastructures for evaluation and research provide the basis for policy learning (and adjustment) involving various ministries and research communities. 


\section{The evolutionary point of departure}

The point of departure is represented by the evolutionary perspectives on how resources created as externalities of current industrial configurations channel development in certain directions at the expense of others. In contrast to orthodox economic thinking, here, the role of government is not limited to correcting 'market failures' that arise because natural monopolies, collective goods and externalities do not provide individual actors with full information, clearly articulated preferences and well-protected property rights to negotiate with each other until a Pareto optimum is reached (Groenewegen and van der Steen, 2007; Peneder, 2017). Instead, it is one where governments must facilitate, guide and sometimes actively steer development processes that are cumulative, collective and often fundamentally uncertain (Hodgson, 1999). This involves interacting with (reinforcing or counteracting) processes of novelty creation, selection and subsequent accumulation of productive resources that are endogenous to the industrial system itself (Nelson and Winter, 2002; Nelson and Winter, 1982) and therefore specific to each territorial economy. This is a demanding task with high requirements regarding the quality of governments (Rodríguez-Pose and Garcilazo, 2015) and involves risks of regulatory capture (Laffont and Tirole, 1991). Hence, a well-functioning institutional framework is paramount for it to work (Farole et al., 2010; 2011).

The basic premise is that economies learn from what they are currently doing and are constrained in their ability to do differently by what they are not (Hausmann, 2016; Hidalgo et al., 2007; Neffke et al., 2011). From this follows that the entry and exit of activities reflect as much specific conditions in the economy in question as it reflects the actual value creation potentials of different economic activities. A second basic premise is that resources are created through interactions between different types of knowledge (analytical, synthetic, and symbolic) and generated in different ways (spanning from R\&D to 'learning-by-doing' in specific contexts of technology application). Because it is not confined to certain activities (R\&D) or actor groups (high-tech firms, universities, venture capitalists, R\&D specialists), research and policy attention must be awarded to complex patterns of resource generation, accumulation and integration occurring at the intersection between different actors and occupations. By focusing on the breadth and nature of society-wide learning rather than the depth and quality of scientific research, this positions recent evolutionary thinking in opposition to the emphasis of mainstream innovation studies and policy during the 2000s on the R\&D efforts, technology portfolios and university-industry linkages of territorial economies (Jensen et al., 2007).

In line with this, territorial economies are increasingly described in terms of their employment compositions (Boschma et al., 2014; Neffke et al., 2011; Boschma and Iammarino, 2009; Frenken et al., 2007) or export baskets (Saviotti and Frenken, 2008; Hidalgo et al., 2007). In this perspective, each industry or export specialization is assumed to reflect a specific industrial 'capability' that is also a learning domain 
composed of actor groups that span from researchers to venture capitalists, industrial owners and banks, managers, politicians and workers, in general. The localized nature of these processes stems from how the more generally accumulated experience-based knowledge and interpersonal network ties formed through career paths of researchers, managers and workers are shaped by current industrial configurations. Notably, it is also evident from venture capital preferences for investments close to home, in technology and market areas where it has prior experiences and the strongest networks.

This suggests that high 'relatedness density', i.e. territorial specialization in several different-yet-related learning domains, increases the capacity of regions to diversify into new higher value added activity because new structures can be built more easily by using existing components (Hausmann, 2016; Boschma, 2017). Entrepreneurial new firm formation occurs most intensively, with the highest probabilities of success, when drawing, in different ways, on spillovers (Acs et al., 2009) from similar or 'related' incumbent industries is illustrative of this (Andersson and Klepper, 2013; Neffke et al.2011). Moreover, incumbent firms capture learning benefits when the surrounding economy allow recruitment from different-yet-related industries (Aarstad et al., 2016; Herstad et al., 2015; Timmermans and Boschma, 2014; Solheim et al., 2020). By implication, strong territorial specialization should not only weaken the innovation performances of individual firms (as exposure to new insights and skills from different yet related industries is limited), but also reduce the capacity of economies to enter into new activities (as the scope for 'related' diversification is limited). Conversely, high diversity (unrelated variety) should come with the benefit of portfolio effects that protect regions against sectorspecific shocks, and the disadvantage of limited cross-fertilization between different activities due to lack of 'fit' between the resources that each create, and depend on. Thus, the ability of different economies to self-transform from within can be summarized as follows:

- Specialized regions (low related and unrelated variety) have a limited capacity to self-transform from within through diversification unless new capabilities are introduced exogenously. Thus, endogenous development is limited to path extension (positive lock-in to current specialized activities) or path exhaustion (negative lock-in to current activities);

- Regions characterized by 'related variety' have a particularly strong capacity to 'self-transform' from within by developing new activities in areas that are related to current activities (path branching) and by strengthening the innovation capacities and productivity performances of individual firms (crossfertilization). Yet, diversification is incremental, and conservative;

- Unrelated variety is the absence of a single and clearly defined regional path in a context of diverse economic activity. It is characteristic of urban economies, where diversity reproduces itself as a portfolio advantage that shelters economies from sector-specific shocks yet limits inter-industry learning and 
interdependencies due to labour market segmentation and weak inter-industry collaborative linkages (cf. The notion of urban fragmentation, see Tödtling and Trippl, 2005; Herstad, 2017). Urban diversity does facilitate innovation and growth in knowledge-intensive services (Herstad et al., 2019), and comes with a large potential for radical innovation and new path creation more generally. Yet, large initial cognitive distances between different pieces mean that harnessing this potential beyond the services sectors that concentrate in cities requires policy intervention.

\subsection{New path development ${ }^{1}$}

Without the requisite knowhow and routines (distributed over various actor groups and shaped by ongoing activities), it is difficult for economies to diversify into entirely new fields, thus limiting diversification to fields that are closely 'related' to existing ones (Neffke et al., 2011). This applies even though high value creation potential in a new field is paralleled by limited potentials in current ones. This 'chicken and egg' dilemma (Hausmann, 2016) draws attention to the concept of path dependency (Martin and Sunley, 2006), as captured by recently developed typologies (Grillitsch and Trippl, 2016; Grillitsch et al., 2018) summarized in Table 1. Path extension is the continuation of existing industrial activities through incremental innovations that build on established organizational practices and evolve along established technological trajectories. It is foremost based on knowledge created within these existing industries, partly through specialized R\&D efforts aiming to solve specific problems and partly as externalities of their broader business activities. Limited generation of or access to new complementary knowledge and deepening specialization constrain the innovation potential of regional industries and may result in stagnation and decline (Isaksen and Trippl, 2016).

Path upgrading points to major intra-path changes, that is, changes of an existing regional industrial path into a new direction. One can distinguish between three subcategories of upgrading. First, such processes could be triggered by the infusion of new technologies or major organizational changes (renewal). The introduction of new digital technologies (e.g. Industry 4.0) would be an example of renewal by using these new technologies to increase firms' productivity. Second, upgrading can be related to an improvement of the position of the regional industry within global production networks (climbing GPNs). This may take place through processes of value enhancement based on the development of more advanced functions, more specialized skills, etc. (Coe et al., 2004; MacKinnon, 2012). Third, upgrading might also be related to the development of niches in mature industries (niche development). This could, for instance, be driven by the addition of symbolic knowledge (e.g. in the food and beverage industry as well as in tourism).

\footnotetext{
${ }^{1}$ This section is in parts based on Grillitsch et al., (2018).
} 
Table 1. Types and mechanisms of new regional industrial path development

\begin{tabular}{ll}
\hline Types of path development & Mechanisms \\
\hline Path upgrading & $\begin{array}{l}\text { Major change of a regional industrial path related to } \\
\text { enhancement of position within global production } \\
\text { networks moving up the value chain based on } \\
\text { upgrading skills and production capabilities }\end{array}$ \\
\hline II-Climbing GPN & $\begin{array}{l}\text { Major change of an industrial path into a new } \\
\text { direction based on new technologies (e.g. Industry } \\
\text { 4.0) or organizational innovations, or new business } \\
\text { models }\end{array}$ \\
\hline $\begin{array}{l}\text { III-Niche development } \\
\text { symbolic }\end{array}$ & $\begin{array}{l}\text { Development of niches through integration of } \\
\text { knowledge }\end{array}$ \\
\hline Path diversification & $\begin{array}{l}\text { Diversification into a new related industry for the } \\
\text { region building on competencies and knowledge of } \\
\text { existing industries (regional branching) }\end{array}$ \\
\hline II- - Related & $\begin{array}{l}\text { Diversification into a new industry based on unrelated } \\
\text { knowledge combinations (e.g. digital technologies } \\
\text { and other types of key enabling technologies (KET)) }\end{array}$ \\
\hline Emergence & $\begin{array}{l}\text { Setting up of an established industry that is new to the } \\
\text { region (e.g. through non-local firms) and unrelated } \\
\text { with existing industries in the region }\end{array}$ \\
\hline I- Path importation & $\begin{array}{l}\text { Emergence and growth of entirely new industries } \\
\text { based on radically new technologies and scientific } \\
\text { discoveries or as an outcome of search processes for } \\
\text { new business models, user-driven innovation and } \\
\text { social innovation }\end{array}$ \\
\hline II - Path creation &
\end{tabular}

Source: Grillitsch et al., 2018

Path importation refers to the setting up of established industries that are new to the region and not related to other industries present in the region. Such processes could be triggered by the arrival of non-local companies, inflow of skilled individuals with competences not previously available in the region or innovation partnerships with distant sources. Inward investment by non-local companies is often seen as a key route for path importation, particularly if these firms feature high valueadded functions and embed themselves in the regional economy by creating links to regional actors (Aitken and Harrison, 1999; Smarzynska Javorcik, 2004; Ebersberger and Herstad, 2012).

Table 1 conceptualizes related and unrelated path diversification depending on the relatedness of the knowledge or sector used in the diversification process. Related diversification - also referred to as regional branching - requires both 
knowledge and sector to be related, which is the most common form of industrial development according to evolutionary economic geography (Hidalgo et al., 2018; Neffke et al., 2011). Related diversification implies that new regional industrial paths emerge building on the capabilities in existing industries. Such processes may have several sources. An important mechanism is the diversification of incumbent firms into related fields and industries based on the redeployment of existing assets (Neffke and Henning, 2013). Branching can also occur through the foundation of new firms based on the competencies in existing industries. Spinoffs from incumbents have been found to play a key role for path branching (Klepper, 2007; Klepper, 2001). An example would be a car manufacturer diversifying into the production of trucks.

Unrelated diversification represents cases where either knowledge or sector is unrelated. Path diversification based on unrelated knowledge combinations occurs when firms combine their existing knowledge base with new, (previously) unrelated knowledge. In this regard, the knowledge base concept, differentiating between analytical, synthetic, and symbolic knowledge (Asheim, 2007), provides the theoretical background to numerous empirical studies. The three knowledge bases (analytical, synthetic and symbolic knowledge) differ substantially in many respects; still, their combination is feasible and conducive for innovation processes (Grillitsch et al., 2017). New combinations of knowledge bases seem to become increasingly important as sources of new path development (Asheim et al., 2017), not the least in connection with key enabling technologies (KET) (Bellandi et al., 2018). Evidence suggests that such new combinations happen in innovation processes through different mechanisms such as collaborations, recruitment, strategic alliances, or acquisitions. The experimental and evolutionary character of new path development is at the heart of this argument. The starting point is the search for competitiveness and high value-creating activities driven by entrepreneurs. In order to become more competitive, entrepreneurs experiment in innovation processes, where the combination of unrelated but complementary knowledge offers a high potential for introducing novelty. Successful experiments signal viable business opportunities to the market.

A case of related knowledge but unrelated sector is the diversification of the ski manufacturer Fischer (Austria) to the aviation industry by using its cutting-edge knowledge of composite materials (Grillitsch et al., 2018). A case of related sector but unrelated knowledge is the diversification of the food industry, which can be characterized as a traditional industry resting on synthetic knowledge, into functional foods by introducing knowledge from biotechnology (Asheim and Coenen, 2005). The introduction of science-based, analytical knowledge from biotechnology has led to the generation of high value-added functional foods with particular health benefits (Zukauskaite and Moodysson, 2016). A similar example would be traditional textile and shoes industries moving into technical textile and shoes by adding 
nanotechnology (analytical knowledge base) to the traditional (synthetic) knowledge base of the industry.

Table 2. Unrelated diversification: New combinations of related and/or unrelated knowledge

\begin{tabular}{lll}
\hline $\begin{array}{l}\text { Knowledge } \\
\text { Sector }\end{array}$ & Related & Unrelated \\
\hline Related & $\begin{array}{l}\text { Related diversification } \\
\text { e.g. car } \rightarrow \text { trucks }\end{array}$ & $\begin{array}{l}\text { Unrelated diversification } \\
\text { e.g. food } \rightarrow \text { functional food } \\
\text { based on biotechnology }\end{array}$ \\
\hline Unrelated & $\begin{array}{l}\text { Unrelated diversification } \\
\text { e.g. ski } \rightarrow \text { aviation based on } \\
\text { composite material }\end{array}$ & $\begin{array}{l}\text { New path creation } \\
\text { e.g. attracting and anchoring } \\
\text { actors/knowledge from outside } \\
\text { the region }\end{array}$ \\
\hline
\end{tabular}

Source: Authors' representation

When both knowledge and sector are unrelated to existing industries in the region, this is not diversification but new path creation. Path creation into new industries represents the most radical form of change. It is brought about by the emergence and growth of industries based on new technological and organizational knowledge. There is a growing consensus that chance or historical accidents should not be overemphasized as causes of new path creation, because they often emerge 'in the context of existing structures and paths of technology, industry and institutional arrangements' (Martin and Simmie, 2008), such as an excellent scientific base (Martin and Sunley, 2006). The emergence of new high-tech and knowledge-intensive industries often hinges on the establishment of new companies and spin-offs (Bathelt et al., 2010). This typically requires the acquisition and anchoring of actors and knowledge from extra-regional scales (Binz et al., 2016; Isaksen and Trippl, 2017). While path upgrading, regional branching and path importation represent strategies to capture (current) value creation potential, unrelated path diversification and new path creation are strategies to create new value creation potential.

\subsection{Regional knowledge dynamics and international linkages}

Localized knowledge dynamics are not only local (Bathelt et al., 2004). On the contrary, they simultaneously shape and are themselves shaped by the extraregional linkages that regions maintain (Herstad, 2017; Ebersberger et al., 2014, Grillitsch and Nilsson, 2015). Spillovers due to relatedness density may provide firms with resource support for internationalization (Fernhaber et al., 2008; Herstad and Ebersberger, 2015), and strengthen the capacity of regions to absorb, assimilate and transform this knowledge into impetuses for further innovation and growth 
(Boschma and Iammarino, 2009). Presumably, this works through the two complementary mechanisms that are i) effective local diffusion of spillovers in support of internationalization, such as information about international opportunities and human resources in support of their pursuit (e.g. Fernhaber et al., 2008), and ii) regional absorptive capacity (Meyer and Sinani, 2009; Herstad and Ebersberger, 2015; Boschma and Iammarino, 2009). If this is the case, as the available evidence suggests, it means that highly specialized economies are in a disadvantaged position in terms of establishing and capitalizing on the non-local knowledge flows that they are particularly dependent on. This suggests that there is a 'double disadvantage' to strong territorial specialization where firms become trapped (cf. Laursen et al., 2012) by specialized home regions where local spillovers stimulate further specialization.

\subsection{New perspectives on innovation policy}

Based on this line of reasoning, it is commonly argued that innovation policies should circumvent the 'chicken and egg' dilemma by supporting new industrial activities that are 'related' to current ones (Balland et al., 2019) yet have higher value added potentials and higher levels of complexity (in terms of skills and technology). This is because such strategies are those with the highest probability of success. Notably, 'technology intensity', the traditional guiding principle for higher value added and protection against price-based competition is here substituted by two other concepts: First, the concept of 'relatedness density', which captures the dynamic interplay between industries. Second, the concept of 'complexity', which is the inverse of ubiquity and thus addresses the risk of price-based competition due to imitation (Hidalgo and Hausmann, 2009; Boschma, 2016; Mewes and Broekel, 2020).

While this line of reasoning is a welcome response to the fundamental limitations of the Lisbon strategy, there are both conceptual and empirical reasons to question whether excessive emphasis is currently put on 'relatedness density' as the new guiding principle for policies. At the outset, it can be argued that advice for policy to focus on supporting diversification into 'related activities' is very close to saying that it should only work towards reinforcing evolutionary processes already at play, i.e. strengthening 'branching' at the fringes of the current development path. Doing so assumes that 'high relatedness density' is always a welcome state where negative lock-ins do not exist, and raises questions concerning the additionality, and thus long-term social returns, of policy intervention (cf. Heggedal, 2015).

Empirical research also gives reason to nuance the 'relatedness density' argument as applied to policy. For instance, different 'varieties of capitalism' foster different patterns of diversification by representing institutional incentives and constraints for collective action that are strongly embedded in the very fabric of societies, and thus difficult to change (Boschma and Capone, 2016; Herrmann and Peine, 2011; Filippetti and Guy, 2020). Moreover, complex and cumulative 
manufacturing industries depend more on regional specialization than the now rapidly growing services industries where innovation appears to depend foremost on exposure to diversity of insights and experiences (Herstad, 2018a; Solheim et al., 2018; Jøranli and Herstad, 2017). Finally, studies have argued that R\&D intensity increases the firm-level capacity to exploit diverse experience-based knowledge (Solheim and Herstad, 2018), and the capacity of regions to engage in unrelated diversification (Xiao et al., 2018). This is particularly notable in the light of research suggesting that related variety foremost promotes short-term growth, whereas unrelated variety is important for economies to keep growing in the long run (Saviotti and Frenken, 2008).

This leads to a final, general point. Growth is driven by processes of technological change through which not only new products but also entirely new industries are created. Logically, as illustrated by the examples provided above, this means that historical data on relatedness between established product technologies and industry domains may be of limited value as indicators of what will be the most dynamic complexes of 'relatedness' in the future. If this fundamental limitation to the use of historical product space configurations and current relatedness matrixes for the purpose of developing forward-looking policy advice is not acknowledged, it advises regions to attempt 'backward convergence' towards the clusters of dynamically related industrial capabilities that provided the most potent impetuses for growth in other regions, in the past. Little room is then left for entirely new product technologies and new industries to redefine regional 'landscapes of relatedness', and thus for radical innovation based on new combinations of (previously) unrelated knowledge. Thus, Zhu et al. (2017) note in their study of Chinese exports: 'Rather than focusing on path dependent regional diversification, analyses (...) should pay more attention to the role of firm agency, local social and institutional contexts, policy making and extra-regional linkages in reducing regions' reliance on relatedness' (Zhu et al., 2017).

\section{The building blocks of a theory}

This line of reasoning suggests that one has to acknowledge basic evolutionary processes at play in the economy, and then look beyond these processes in order to find theoretical and ontological arguments to underpin new policy perspectives. Much like orthodox economics, evolutionary theories lack a social ontology. As a result, 'social agency' is underdeveloped. This limits the scope for new policy initiatives for new path development that goes beyond what has worked in the past. Moreover, it does not allow space for preparing for serendipity and 'black swans', the unexpected and sometimes pleasant outcomes of economic activity. It also limits the scope for the more long-term perspective of promoting economic activities that have higher knowledge and technology complexity than previous industries but are 
yet located outside or at the periphery of the current regional 'revealed related variety' complex.

In this perspective, regional circumstances may demand policies aimed to explore (previously) unrelated combinations of knowledge and technology for the purpose of growing the new complexes of 'high relatedness density' that constitute a new development path (e.g. new path creation). These may give higher long-term benefits but are admittedly associated with higher risks compared to the 'safer' strategy of the more short-term perspective of supporting industries with high relatedness to the existing knowledge base (Balland et al., 2019, see Figure 1). Clearly, a strategy based on the exploration and exploitation of (previously) unrelated knowledge combinations demand that mechanisms ensuring that more knowledge is diffused between sectors than that occurring through existing collaborative ties and labour market segments are at play. Thus, it draws attention to the need for regional knowledge diffusion infrastructures, i.e. regional innovation systems, to serve in support of such exploration.

We also expect that unrelated knowledge combinations will increase in importance with the availability and improved accessibility to general-purpose technologies or key enabling technologies (KET), such as ICT, biotech, nanotech, etc., providing the basis for more transformative forms of new path development in the future (Asheim, 2019). This further underscores the importance of regional research institutions engaging with regional actors on a long-term, committed basis. For example, as part of the regions' smart specialization strategy, in Emilia-Romagna, emphasis has been put on introducing general purpose technologies such as nanotechnologies, advanced materials, microelectronics, photonics, industrial biotechnologies, advanced production systems and digital technologies into the knowledge bases and innovation processes of traditional firms that largely depend on an experience-based DUI mode of innovation. The aim is to foster the emergence of new and highly innovative industrial systems. They do this by reinforcing the regional innovation system by promoting investment in industrial $\mathrm{R} \& \mathrm{D}$, research-industry collaboration, and an increase in highly educated jobs to make the manufacturingoriented system competitive in a knowledge based global economy (Bertini, 2017).

In exploiting such opportunities, entrepreneurial discovery can play a key role. However, potential entrepreneurs are not only innovative entrepreneurs in the business sector but also institutional entrepreneurs in universities and the public sector as well as place-based leaders and actors in the civil society (Grillitsch and Sotarauta, 2020). General-purpose technologies will also, normally, be more available globally than locally, and if sourced from outside the region, the region does not have to develop 'new technologies from scratch' (Balland et al., 2019, p. 1260). This underlines the importance of supporting non-local, global knowledge sourcing and links, and designing policies to facilitate this taking place, e.g. by transnational and inter-regional benchlearning. Consequently, such 'high risk/high benefit' alternatives will not represent a 'casino' strategy '(Ballard et al., 2019, p. 
1260) but transformative activities based on unrelated knowledge combinations that go beyond just sectoral renewal as the 'high benefit/low risk' alternative represents (Asheim, 2019). Hidalgo et al. (2007, p. 482) emphasize how structural transformation through adaptation to proximate opportunities are fundamentally different from the adaptability that is required when a country hits a dead-end ${ }^{2}$ and production needs to shift to far-away positions in the product space.

\section{Figure 1. Framework for Smart Specialization policy}

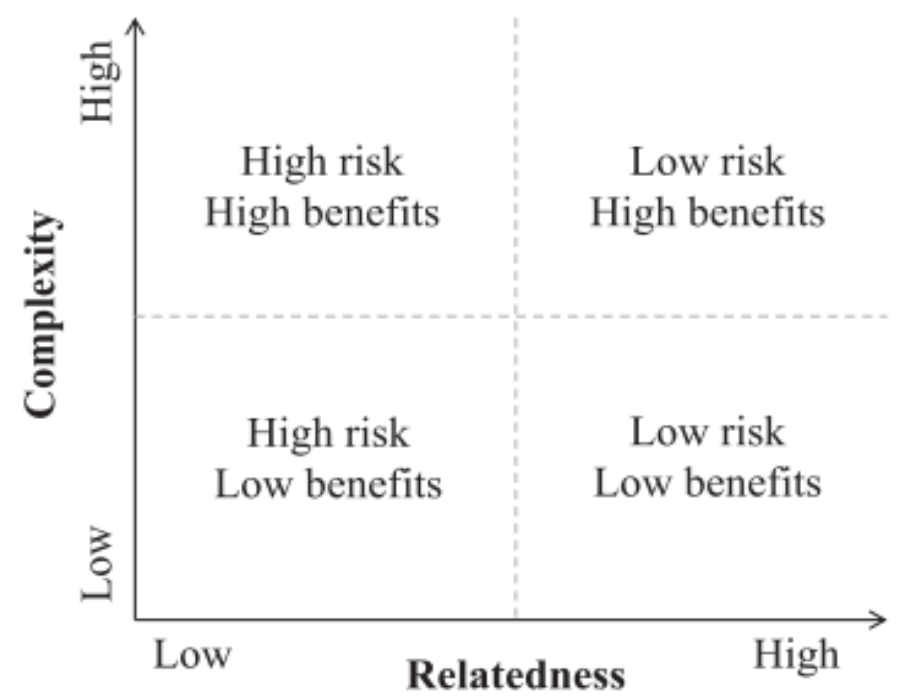

Source: Balland et al., 2019, p. 1259

Thus, research increasingly focuses on the potential of unrelated diversification as a more important source of economic diversification and new path development, especially in a long-term perspective (Grillitsch et al., 2018; Saviotti and Frenken, 2008). Pinheiro et al. (2018) found that countries at low levels of development tend to be close to products that are of a low level of complexity, meaning that they see an option set with a negative correlation between relatedness and complexity (i.e. the most unrelated products are the most complex). At high levels of development, countries are confronted with an opposite option set: higher complexity products are among the most related. So, the low hanging fruits of developing countries mostly include products of low complexity, whereas the low hanging fruits of developed countries mostly include sophisticated, complex products. The authors found that unrelated diversification tends to happen at an intermediary stage of economic development, given that the countries have higher

\footnotetext{
${ }^{2}$ An example of such dead-ends would be industries reaching a stage of 'path exhaustion'.
} 
levels of human capital (e.g. South Korea in the 1980s). Data shows that countries that enter more unrelated activities experience an increase in short-term economic growth of $0.5 \%$ per annum compared to those with similar levels of income, human capital, capital stock per worker, and economic complexity. However, in another article, Xiao et al. (2018) found that increasing innovation capacity leads to reduced importance of relatedness for industrial diversification. They conclude that 'high innovation capacity allows an economy to break from its past and to develop truly new industry specializations' and, consequently, that 'innovation capacity is a critical factor for economic resilience and diversification capacity' (p. 1). These findings seem to contradict the findings of Pinheiro et al. (2018) and lend empirical support to OECD's claim that, due to its long term and pro-active innovation policy, the high-tech economy of Sweden is the most resilient economy in Europe, as it always comes out of crises by doing something more advanced and complex (OECD, 2013). This underlines the critical importance of public policy in promoting especially long term and transformative forms of new path development in advanced economies.

\section{Innovation policy in the evolutionary landscape}

From the perspective of policy formulation, three points from the above are essential. First, that skills and organizational routines developed as externalities of past and current industrial activities represent resources that are unique to regional economies, and, depending on complexity, difficult for other regions to imitate. These resources i) can be reconfigured into new activities; yet, ii) their specific content imposes constraints on how new activities can be developed without active intervention. Second, while stimulated by co-location, industry itself has a limited capacity to explore new combinations of (previously) unrelated knowledge: Labour market segmentation and lock-ins to established networks with defined 'insiders' and 'outsiders' (Giuliani, 2007) entail that knowledge foremost diffuses, and diversification predominantly occurs at the intersection between industries already identified as 'related'. Firms will prefer to recruit from where they find skills that are relevant to their current activities, and employees will respond to the wage structures that form as a result. Collaboration networks will be established between partners with capabilities that are complementary today, and new activities will emerge and will be most attractive to investors, where alternative value in these skills and capabilities is most transparent (low risk due to high relatedness). Third, and finally, the ability of national economies to establish international linkages to upgrade value chain positions or access and exploit complementary knowledge is also shaped, or limited, by current configurations and the 'related variety' that is already revealed.

Logically, this first draws attention to the efforts aimed at increasing the capacity to explore new combinations of knowledge and capabilities. In line with this, the concept of entrepreneurial discovery processes is essential in the literature 
on smart specialization that advises regions to foster strategic technological diversification around their core activities (McCann and Ortega-Argilés, 2013). The concept links closely to the related variety argument (related diversification), yet, at the same time, it also emphasizes policy frameworks which facilitate processes of entrepreneurial discovery across different domains (Foray, 2014a; McCann and Ortega-Argilés, 2014): Activities that are transformative because they involve unrelated, as clearly delineated from related, diversification. The rapid assimilation of the concept into European regional cohesion policy (and the slower diffusion of the concept into $R \& D$, industrial and innovation policy more generally) suggests that it resonated with a broadly and strongly felt need for theoretical perspectives allowing regions to prioritize their development efforts (vertical policies). This shift of emphasis in the field of regional development echoes the New industrial (innovation) policy literature, in which the state has been rehabilitated as an economic actor and enjoined to work in and through networks to catalyse innovationbased development (Morgan, 2017; Lauridsen, 2017; UNCTAD, 2018).

The important point here is that smart specialization has become a focal point for different strands of literature that emphasize the role of government in policies that take as their point of departure the different resource conditions and histories of different regions (Peneder, 2017). This raises, in itself, multiple questions concerning the design and implementation of innovation policy and tools supportive of the entrepreneurial discovery process, including that of how to organize for the policy learning required when governments are to take on more active roles (Groenewegen and van der Steen, 2007). At the same time, it forces one to acknowledge that, in some regions, further diversification may not be possible unless new capabilities are acquired. Here, the policy challenge is not so much one of strengthening connections across (previously related or unrelated) domains, as one of overcoming the above-mentioned 'chicken and egg' dilemma where the initial absence of knowhow provides barriers to its future accumulation. Such situations are characterized by a large discrepancy between potential social returns through dynamic implications (of the new capability if introduced), and the returns that private actors investing in the technology can expect. While Hausmann (2016) notes that 'in those circumstances, it would be appropriate for the government to promote the acquisition of key capabilities', neither evolutionary economic geography, nor the product space approach of Hausmann et al. (2009) provide insights into how countries initially acquired their capabilities, nor how they should act to acquire new ones with potential for reinvigorating evolutionary dynamics.

This crucial point warrants attention. If a 'capability' is conceptualized as stemming not from discrete R\&D but from interactions between a wide range of actor groups (researchers, investors, managers, employees) and types of knowledge (analytical, synthetic, symbolic), acquiring a capability is not equal to investing in research. Adding a capability to an economy entails anchoring and growing activities that foster broad-based learning in the economy and feed on global networks. This 
involves upscaling beyond research to develop the knowhow that is constitutive of 'capability'. These challenges are particularly pressing in, third, those cases where the transformation of entire socio-economic systems are needed (cf. the concept of transformational innovation policy as used in the sustainability transition literature, see Weber and Rohracher, 2012). As the role of policy in such transformations cannot be understood from the perspective of bottom-up entrepreneurial discovery, nor from the orthodox perspective of hands-off, they draw attention to the "new industrial policy' literature.

Initially, this literature drew heavily on historical evidence, in particular from Japan (post-war industrialization guided by MITI) and the US (the military-industrial complex in general and the Advanced Research Projects Agency (ARPA) in particular). Currently, it is drawing inspiration from sustainability transitions in countries such as China, Germany (Fischer et al., 2016; Joas et al., 2016; Reichardt and Rogge, 2016; Fornahl et al., 2012), Great Britain (Simmie et al., 2014) and Denmark (Simmie, 2012) when emphasizing that the role of governments and policy extends far beyond that of correcting 'failures'. It includes the creation of shared visions regarding the direction of change, coordination across different levels of governance (regional and national) and multiple policy fields (e.g. education, R\&D and innovation), and, importantly, the establishment of spaces for experimentation and learning (Groenewegen and van der Steen, 2007), where failure is legitimate. In that sense, it acknowledges the complex, multi-faceted and distributed nature of 'capability' as conceptualized in evolutionary theory. Using concepts such as the 'entrepreneurial' (Mazzucato, 2013), 'developmental' (Block, 2008; Wade, 2017) or 'embedded' (Morgan, 2017) state, and emphasizing how industrial policy is commonly concealed as public health or security policy to avoid conflict with official industrial policy as prescribed by orthodox economics, this literature underscores the importance of directionality as clearly delineated from both neutrality and picking winners. Moreover, it emphasizes the transformative forces created when governments are willing to intervene across the entire innovation value chain spanning basic research to market creation (Mazzucato, 2016; Guerzoni and Raiteri, 2015; Weber and Rohracher, 2012; Peneder, 2017).

At this point, the literature on NIP and smart specialization gains support from evolutionary theory when suggesting that neither specific projects nor specific policies or tools should be implemented and evaluated on an individual basis. Instead, the benchmark for success, at the project level, is not value creation from the project itself, but whether it contributes a constituent component of a new capability. This, in turn, draws attention to the policy mix discussion, in which the concept of complementarities is essential at the theoretical level, yet difficult to acknowledge and capture in empirical research and real-life policy design (Flanagan et al., 2011; Reichardt and Rogge, 2016; Rogge and Reichardt, 2016). 'Complementarity' must be understood here as 'super-modularity', meaning that the 
effect of one set of policies, or policy tools, is greater in the presence of other policies and tools that have a specific content (Herstad et al., 2010).

The first dimension concerns complementarities between supply-side and demand-side intervention. Here, the idea is that supply-side intervention, such as funding of strategic basic or applied research has a stronger impact on structural change in the economy if complemented by demand-side intervention, such as public procurement for innovation or market regulation that gives actors incentives to engage in activities that lead to the accumulation of knowhow and the development of industrial capabilities. The classic example is that of complementarities between federal R\&D funding ('supply-side') and defence contracts ('demand-side') in the US during the Cold War. This dimension remains highly relevant, and a recent study found supply-side technology policies effective only when interacting positively with demand (Guerzoni and Raiteri, 2015). The attractiveness of complementary (to investments in basic and applied research) demand-side intervention stems from incentives provided for commercial actors (firms with their investors, employees and partners) to develop the knowhow and capabilities required for viable commercial activity on a large scale.

The second dimension along which complementarities (or contradictions) must be considered derives from this and concerns firm-level versus system-level types of policies (Herstad et al., 2010). Arguably, structures and incentives seeking to broaden and speed up knowledge diffusion between firms should be viewed as strongly, and fundamentally, complementary to efforts aimed at strengthening knowledge development and accumulation within them (as this increases the amount of knowledge externalities they dispatch, and the capacity to absorb incoming externalities). This follows directly from the market failure argument in orthodox economics, from which effective knowledge diffusion between firms, i.e. wellfunctioning systems, can be expected to reduce their willingness to invest in generating knowledge, i.e. market 'failures' (Herstad, 2018b). It also follows from evolutionary thinking, as overcoming the 'chicken and egg' dilemma demands that firms invest in the generation of knowhow that is new to the economy in question in spite of the high risk that this involves and the constraints met among actors that span from investors to employees due to the initial absence of requisite knowhow.

The balance between initiatives seeking to build R\&D capacity in firms and those seeking to strengthen applied R\&D in the science system is related to this. The strong policy emphasis of the last decade on technology commercialization and university-industry linkages is commonly reflected in industry R\&D funding schemes that stimulate contractual R\&D sourcing from universities or other public research institutions. This is at odds with the 'market failure' argument for R\&D support to industry, as it provides firms with the option of downscaling their internal $\mathrm{R} \& \mathrm{D}$ efforts, and with the 'system failure' argument in that contractual $\mathrm{R} \& \mathrm{D}$ involves limited knowledge transfers (Fey and Birkinshaw, 2005). Moreover, it is in conflict with research finding that firms capture the strongest learning effects when 
they balance strong intramural $\mathrm{R} \& \mathrm{D}$ efforts with selective rather than large-scale extramural R\&D (Grimpe and Kaiser, 2010; Cassiman and Veugelers, 2006; Ebersberger and Herstad, 2011; Gkypali et al., 2017). Of particular importance in the context of path dependency and structural change, studies have suggested that in-house basic research is critical for the capacity of firms to generate radical innovations (Añón Higón, 2016; Herstad, 2018a) and indicated that external R\&D purchases may lead to downscaling of intramural $R \& D$ efforts over time (Teirlinck et al., 2010).

As the main point here is related to the policy implications for industrial learning and capability building in new technology and market domains, it is notable how Landini and Malerba (2017) find radical technological change generating particularly strong complementarities between support for learning at the firm level and other, more exploration-oriented initiatives. This is because the former favours the accumulation of skills and routines (in new areas) that is critical for activities to grow and impact (on skill-formation and further diversification in) the economy, while the latter speeds up the search for new opportunities (Landini and Malerba, 2017).

Finally, it is well established that internal R\&D capacity is an important determinant of firms' capacity to engage in international networking (Herstad et al., 2014; Herstad and Ebersberger, 2015) and for their capacity to access, assimilate and exploit complementary international knowledge (Chen et al., 2016) - not least among technology-based SMEs (de Jong and Freel, 2009). In this sense, the traditional market failure argument of orthodox economics align with the 'chicken and egg' dilemma emphasized in evolutionary theory: Both imply that incentives for knowledge development and accumulation in firms are strongly complementary to the efforts aimed at increasing the intensity and scope of knowledge diffusion between firms and industries (Herstad et al., 2010). This calls for system-level policies for exploring related and unrelated knowledge combinations (Coenen et al., 2016).

A final issue concerns the geographical configuration of innovation systems. Here, two closely related aspects must be considered. A territorial innovation system consists of the relationship between an industrial structure (containing specialized knowhow and capabilities) and supportive research institutions (linking different industries and providing complementary research-based knowledge). The first aspect concerns that of within-economy centralization (a strong national innovation system) versus decentralization (to build diverse regional innovation systems supportive of regional entrepreneurial discovery processes). Arguably, centralization provides the basis for a limited number of large research institutions to co-evolve (through domain-specific learning) with (dominant incumbent) industries (Narula, 2002; Herstad and Sandven, 2017; Claussen, 2009). This, in turn, provides the basis for the research system to resolve the tension between research quality and relevance to industry by focusing on activities that are supportive of incumbents, and should therefore strengthen the economy-level capacity for related diversification as leading research institutions 
link (related knowledge diffusion) and support (complementary technological development) related (incumbent) industries located in different regions.

In essence, centralization strengthens the capacity for path extension and path branching at the national level and dampens tensions between research excellence and industry relevance. However, centralization also comes with reduced sensitivity to diversity and the risk of large 'cognitive distance' between research institutions and firms that operate on the periphery or outside current (related) specializations. Presumably, this reduces the capacity of national innovation systems to support experimentation with unrelated knowledge combinations and provide regions with research system support that, in line with smart specialization strategies, reflect their specific industrial structures and resource endowments. Strong (exploration-oriented) regional collaboration networks are particularly important in diverse regions (De Noni et al., 2017), as the learning potential associated with 'unrelated variety' does not necessarily materialize from the local labour market mobility that occurs most intensively within segments of industries already identified as skill-related.

The second dimension concerns the relationship between networks at different geographical levels. At the micro-level, research has demonstrated that innovation and productivity performance at the firm level is less dependent on regional and national collaboration than on international collaboration (Fitjar and Rodríguez-Pose, 2013; Fitjar and Rodríguez-Pose, 2011). Research has also suggested that it is foremost through labour market mobility that regional conditions are beneficial for individual firms (Cotic-Svetina et al., 2008; Power and Lundmark, 2004). At the same time, research has also demonstrated that the knowledge dynamics of regions depend on a good balance between extra-regional networks providing access to complementary skills and capabilities, and intra-regional networks ensuring that knowledge diffuses locally (De Noni et al., 2017; Herstad et al., 2010). Without strong regional networks, the local diffusion of knowledge accessed globally is limited to that occurring as a result of labour market mobility or informal 'information buzz' (the importance of which, some argue, is exaggerated, see Fitjar and Rodríguez-Pose, 2016). As regional knowledge diffusion tends to be asymmetrical (Giuliani 2007), occurring most intensively between industries already identified as skill-related and benefiting firms with advantaged positions in local networks more so than others, regions cannot depend solely on 'local buzz' and labour market mobility for local knowledge diffusion from global network nodes (Asheim et al., 2007; Herstad and Brekke, 2012). This further underscores the role of decentralized, 'constructed' knowledge diffusion infrastructures, i.e. regional innovation systems, that operate in parallel with (and complementary to) strong and broad international networks (Asheim and Isaksen, 2002; Herstad and Sandven, 2017). 


\section{Unrelated knowledge combinations and transformative path creation: Towards a research and policy agenda}

Using the 'foster (regional) related variety' argument of mainstream evolutionary theory as our point of departure, we have argued above that the current landscape of rapid technology and market change, globalization and ongoing sustainability transitions puts a greater demand on innovation and industrial policy to explore the innovation and growth potential of non-local knowledge and (previously) unrelated knowledge combinations. While accepting that related diversification dominates the evolutionary process itself and that the strategies supporting it remain important in the short and medium term, our analysis points to fundamental limitations of related diversification as the main industrial development strategy. They may fail to capture latent local opportunities and emerging opportunities at the international level, increasing the risk that dramatic changes in technology or in the international economy itself (e.g. sustainability transitions) translate into negative lock-ins at the level of territorial economies.

Accordingly, policy needs to step outside the comfort zone of related diversification and stimulate activities that have a higher transformative potential because they are not only characterized by high complexity, but also, at the outset, located at the periphery of the current relatedness complex of territorial economies. Our approach is compatible with the evolutionary theory in that it introduces a distinction between the (current) revealed relatedness of industries, product domains or technologies; and the future (potential) relatedness between (currently) unrelated industries, product domains or technologies - including those not yet existing. Consequently, a parallel distinction can be made between the degree of relatedness density that characterizes current industrial activities and the technologies, products and industries that, in the future, may form entirely different complexes of high relatedness density - and, thus, new development paths characterized by their own distinct forces of development and gradual transformations 'from within'. To approach the complex question of policy design and implementation supportive of the growth of the new critical mass required for new path creation, including that of the policy 'mix' and supportive infrastructures, let us consider three basic functions that need to be served.

The first is exploration of new opportunities, as captured by the concept of 'entrepreneurial discovery processes' in the literature on smart specialization. As pointed out above, a bottom-up approach focusing on exploration of (previously) unrelated knowledge combinations on a systematic basis will normally demand that third-party knowledge diffusion infrastructures (i.e. regional innovation systems built around motivated and competent regional research institutions) serve in support of knowledge diffusion between (currently) unrelated industry segments, and provide access to complementary technology (e.g. key enabling technologies). This facilitator and mediator function must be exerted on an ongoing basis, in close 
contact with industry, and go well beyond that of providing contractual R\&D services to firms. This underscores the importance of regional research organizations and draws attention to the trade-off between centralization for research quality and decentralization for proximity, receptiveness and relevance (Herstad and Sandven, 2017). From this follows the first fundamental question of how the capacity of research and higher education institutions to serve as infrastructures for exploring (previously) unrelated knowledge combinations is influenced by the structure of the research system and the framework conditions (governance, funding, recruitment policies, defined roles and missions) under which institutions are operating.

The second is anchoring and upscaling new activities. Structural change, generally, and new path creation, in particular, only come about when new activities (single firms or, more often, clusters of 'newly related' firms) grow large enough to redefine what 'related' industries in the economy in question (i.e. critical mass) actually are. When, at the outset, new activities are unrelated to current ones, external anchoring points (human resources, investors, partners and markets, research system support) are weak, demanding 'self-anchoring' through upscaling and organizational development at the level of individual firms. This includes the (early) formation of (strong) linkages to markets and partners abroad, reinforcing centrifugal forces and increasing the need for centripetal forces to balance them off. On the one hand, this can be approached as a practical question concerning complementarities between supply-side (research and education), firm-level (support for intramural R\&D) and demand-side (public procurement, market regulation) intervention. It is reasonable to assume that incentives for firms to invest in generating new application-specific knowhow are particularly important when related knowhow is not available in the surrounding economy and the risk of exit therefore is high (Neffke et al., 2011). On the supply side, long-term 'competence programs' based on the model from Sweden may provide important 'platform' support for new activities in selected technological fields and thus provide external anchoring points. Yet, this question extends beyond that of certain types of programs or the specific 'policy mix' to more fundamental ones of 'directionality', commitment, complementarity and coordination. They span from how the 'mix' of innovation policy tools to tax legislation, labour and financial market regulation, public legitimacy and the general policy discourse influence the decision of entrepreneurs (corporate as well as individual) to 'grow' new activities in a given economy and link them up to global networks even though relatedness to current specializations is limited.

The third is the need for policy experimentation and coordination under conditions where failure must be legitimate, success must be determined by the cumulative impacts of different projects and initiatives instead of their individual (technological or 'value creation') performances, while learning and adjustment are essential (Smiths et al., 2010; Groenewegen and van der Steen, 2007). This raises not only questions concerning the division of labour and subsequent coordination between different ministries and levels of governance. It extends into the more 
fundamental issue of criteria and methodologies allowing monitoring and evaluation to provide the basis for learning and development, as well as adjustments of policies in ways that reflect the specific objectives and regional conditions at hand.

\section{Conclusions}

These general principles for promoting the most transformative forms of new path development do neither call for 'picking the winners' strategies of supporting national champions nor for general policies in the form of tax reliefs and subsidies for R\&D investments. These alternatives are either too specific, selecting specific industries under conditions of rapid change and high uncertainty, or too general, attempting to support all industries (Asheim, 2019) and thereby letting evolution run its own course instead of directing it. What is needed are top-down policies that strengthen the macro level innovation supporting infrastructure, e.g. global innovation linkages, and national and regional innovation systems, as in the innovation policy programs of the Swedish governmental innovation agency, VINNOVA, as well as building capacity on the meso and micro levels (institutions, organizations and actors). Such policies do not represent a linear model, but a strategic approach that can be turned into a mission-oriented policy providing directionality to build resources and solve societal challenges. At the same time, such efforts must be complemented with bottom-up experimentation by the regional triple helix stakeholders of the local entrepreneurial discovery process to decide on which specific economic activities to develop. Thus, the entrepreneurial discovery process of the smart specialisation policy would be an additional instrument, which could promote the development of more transformative forms of new path development. In turn, this top-down - bottom-up policy approach should be supplemented by a combination of sector-neutral, horizontal and non-neutral, vertical innovation policies. Building and upgrading R\&D capacity for developing key enabling technologies would be an example of a sector-neutral and horizontal policy aimed at strengthening the exploration capacity of firms and innovation systems, while strategic public demand side policies (e.g. public procurement of innovation) to create markets for sustainable production would represent a non-neutral, vertical policy to increase the exploration and exploitation capacity of firms and innovation systems that would promote unrelated diversification and radical innovations.

Acknowledgement: This paper is partly based on an unpublished scoping paper written for the FORINNPOL program of the Research Council of Norway, January 2018. The economic support is gratefully acknowledged, as is the support provided by the REDINN project to Sverre J. Herstad for work with the paper. 


\section{References}

Aarstad, J., Kvitastein, O.A. and Jakobsen, S.-E. (2016), Related and unrelated variety as regional drivers of enterprise productivity and innovation: A multilevel study, Research Policy, 45(4), pp. 844-856. https://doi.org/10.1016/j.respol.2016.01.013

Acs, Z.J., Braunerhjelm, P., Audretsch, D.B. and Carlsson, B. (2009), The knowledge spillover theory of entrepreneurship, Small Business Economics, 32(1), pp. 15-30. https://doi.org/10.1007/s11187-008-9157-3

Aitken, B. and Harrison, A. (1999), Do domestic firms benefit from direct foreign investment? Evidence from Venezuela, American Economic Review, 89(3), pp. 605618. https://doi.org/10.1257/aer.89.3.605

Andersson, M. and Klepper, S. (2013), Characteristics and performance of new firms and spinoffs in Sweden, Industrial and Corporate Change, 22(1), pp. 245-280. https://doi.org/10.1093/icc/dts046

Añón Higón, D. (2016), In-house versus external basic research and first-to-market innovations, Research Policy, 45(4), pp. 816-829. https://doi.org/10.1016/j.respol.2016.01.005

Asheim, B. (2007), Differentiated knowledge bases and varieties of regional innovation systems, Innovation: The European Journal of Social Science Research, 20(3), pp. 223-241. https://doi.org/10.1080/13511610701722846

Asheim, B. (2019), Smart specialisation, innovation policy and regional innovation systems: what about new path development in less innovative regions? Innovation: The European Journal of Social Science Research, 32(1), pp. 8-25. https://doi.org/10.1080/13511610.2018.1491001

Asheim, B., Coenen, L. and Vang, J. (2007), Face-to-Face, Buzz, and Knowledge Bases: Sociospatial Implications for Learning, Innovation, and Innovation Policy, Environment and Planning C: Government and Policy, 25(5), pp. 655-670. https://doi.org/10.1068\%2Fc0648

Asheim, B., Grillitsch, M. and Trippl, M. (2017), Introduction: Combinatorial Knowledge Bases, Regional Innovation, and Development Dynamics, Economic Geography, 93(5), pp. 429-435. https://doi.org/10.1080/00130095.2017.1380775

Asheim, B.T. and Coenen, L. (2005), Knowledge bases and regional innovation systems: Comparing Nordic clusters, Research Policy, 34(8), pp. 1173-1190. https://doi.org/10.1016/j.respol.2005.03.013

Asheim, B.T. and Isaksen, A. (2002), Regional Innovation Systems: The Integration of Local 'Sticky' and Global 'Ubiquitous' Knowledge, Journal of Technology Transfer, 27(1), pp. 77-86. https://doi.org/10.1023/A:1013100704794

Balland, P.-A., Boschma, R., Crespo, J. and Rigby, D.L. (2019), Smart specialization policy in the European Union: relatedness, knowledge complexity and regional diversification, Regional Studies, 53(9), pp. 1252-1268. https://doi.org/10.1080/00343404.2018.1437900 
Bathelt, H., Kogler, D.F. and Munro, A.K. (2010), A knowledge-based typology of university spin-offs in the context of regional economic development, Technovation, 30(9), pp. 519-532. https://doi.org/10.1016/j.technovation.2010.04.003

Bathelt, H., Malmberg, A. and Maskell, P. (2004), Clusters and Knowledge: Local Buzz, Global Pipelines and the Process of Knowledge Creation, Progress in Human Geography, 28(1), pp. 31-56. https://doi.org/10.1191\%2F0309132504ph469oa

Bellandi, M., Chaminade, C. and Plechero, M. (2018), Transformation paths and multi-scalarity of knowledge bases under Industry 4.0 challenges, CIRCLE Papers in Innovation Studies 14 (retrieved from http://wp.circle.lu.se/upload/CIRCLE/workingpapers/ 201814_bellandi.pdf).

Bertini, S. (2017), Smart specialisation, a strategy to support the transformation of a consolidated manufacturing system: The Emilia-Romagna experience, European Structual Funds and Investment Journal, 5(1), pp. 32-43.

Binz, C., Truffer, B. and Coenen, L. (2016), Path Creation as a Process of Resource Alignment and Anchoring: Industry Formation for On-Site Water Recycling in Beijing, Economic Geography, 92(2), pp. 172-200. https://doi.org/10.1080/00130095.2015.1103177

Block, F. (2008), Swimming Against the Current: The Rise of a Hidden Developmental State in the United States, Politics \& Society, 36(2), pp. 169-206. https://doi.org/10.1177\%2F0032329208318731

Bonaccorsi, A., Čenys, A., Chorafakis, G., Cooke, P., Foray, D., Giannitsis, A., Harrison, M., Kyriakou, D., Pontikakis, D. and Smith, K. (2009), The Question of R\&D Specialisation: Perspectives and policy implications, JRC Technical reports, European Commission.

Boschma, R. (2015), Towards an Evolutionary Perspective on Regional Resilience, Regional Studies, 49(5), pp. 733-751. https://doi.org/10.1080/00343404.2014.959481

Boschma, R. (2016), Smart specialisation and regional innovation policy, Welch Economic Review, 24(1), p. 17.

Boschma, R. (2017), Relatedness as driver of regional diversification: a research agenda, Regional Studies, 51(3), pp. 351-364. https://doi.org/10.1080/00343404.2016.1254767

Boschma, R. and Capone, G. (2016), Relatedness and diversification in the European Union (EU-27) and European Neighbourhood Policy countries, Environment and Planning C: Government and Policy, 34(4), pp. 617-637. https://doi.org/10.1177\%2F0263774X15614729

Boschma, R. and Frenken, K. (2011), The emerging empirics of evolutionary economic geography, Journal of Economic Geography, 11(2), pp. 295-307. https://doi.org/10.1093/jeg/lbq053

Boschma, R. and Iammarino, S. (2009), Related Variety, Trade Linkages, and Regional Growth in Italy, Economic Geography, 85(3), pp. 289-311.

Boschma, R., Eriksson, R.H. and Lindgren, U. (2014), Labour Market Externalities and Regional Growth in Sweden: The Importance of Labour Mobility between Skill- 
Related Industries, Regional Studies, 48(10), pp. 1669-1690. https://doi.org/10.1080/00343404.2013.867429

Cassiman, B. and Veugelers, R. (2006), In search of complementarity in innovation strategy: Internal R\&D and external knowledge aquisition, Management Science, 52(1), pp. 68-82. https://doi.org/10.1287/mnsc. 1050.0470

Chen, Y., Vanhaverbeke, W. and Du, J. (2016), The interaction between internal R\&D and different types of external knowledge sourcing: an empirical study of Chinese innovative firms, $R \& D$ Management, 46(S3), pp. 1006-1023. https://doi.org/10.1111/radm.12162

Claussen, T.H. (2009), Industrial R\&D Policy in Norway: Who Gets Funding and What are the Effects?, in: Fagerberg, J., Mowery, D.C. and Verspagen, B. (eds.), Innovation, Path Dependency and Policy, New York: Oxford University Press, pp. 349-372.

Coe, N.M., Hess, M., Yeung, H.W., Dicken, P. and Henderson, J. (2004), Globalizing' regional development: a global production networks perspective, Transactions of the Institute of British Geographers, 29(4), pp. 468-484. https://doi.org/10.1111/j.0020-2754.2004.00142.x

Coenen, L., Asheim, B., Bugge, M.M. and Herstad, S.J. (2016), Advancing regional innovation systems: What Does Evolutionary Economic Geography Bring To The Policy Table?, Environment and Planning C: Politics and Space, 35(4), pp. 600-620.

Cotic-Svetina, A., Jaklic, M. and Prodan, I. (2008), Does collective learning in clusters contribute to innovation?, Science and Public Policy, 35(5), pp. 335-345. https://doi.org/10.3152/030234208X319357

de Jong, J.P.J. and Freel, M. (2009), Absorptive capacity and the reach of collaboration in high technology small firms, Research Policy, 39(1), pp. 47-54. https://doi.org/10.1016/j.respol.2009.10.003

De Noni, I., Ganzaroli, A. and Orsi, L. (2017), The impact of intra- and inter-regional knowledge collaboration and technological variety on the knowledge productivity of European regions, Technological Forecasting and Social Change, 117(Supplement C), pp. 108-118. https://doi.org/10.1016/j.techfore.2017.01.003

Ebersberger, B. and Herstad, S. (2011), Product innovation and the complementarities of external interfaces, European Management Review, 8(3), pp. 117-135. https://doi.org/10.1111/j.1740-4762.2011.01014.x

Ebersberger, B. and Herstad, S. (2012), Go abroad or have strangers visit? On organizational search spaces and local linkages, Journal or Economic Geography, 12(1), pp. 273295. https://doi.org/10.1093/jeg/lbq057

Ebersberger, B., Herstad, S. and Koller, C. (2014), Does the composition of regional knowledge bases influence extra-regional collaboration for innovation?, Applied Economic Letters, 21(3), pp. 201-204. https://doi.org/10.1080/13504851.2013.848019

Farole, T., Rodríguez-Pose, A. and Storper, M. (2010), Human geography and the institutions that underlie economic growth, Progress in Human Geography, 35(1), pp. 58-80. https://doi.org/10.1177\%2F0309132510372005 
Farole, T., Rodríguez-Pose, A. and Storper, M. (2011), Cohesion Policy in the European Union: Growth, Geography, Institutions, JCMS: Journal of Common Market Studies, 49(5), pp. 1089-1111. https://doi.org/10.1111/j.1468-5965.2010.02161.x

Fernhaber, S.A., Gilbert, B.A. and McDougall, P.P. (2008), International entrepreneurship and geographic location: An empirical examination of new venture internationalization, Journal of International Business Studies, 39(2), pp. 267-290. https://doi.org/10.1057/9781137472311_5

Fey, C.F. and Birkinshaw, J. (2005), External sources of knowledge, governance mode and R\&D performance, Journal of Management, 31(4), pp. 597-621. https://doi.org/10.1177\%2F0149206304272346

Filippetti, A. and Guy, F. (2020), Labor market regulation, the diversity of knowledge and skill, and national innovation performance, Research Policy, 49(1), p. 103867. https://doi.org/10.1016/j.respol.2019.103867

Fischer, W., Hake, J.F., Kuckshinrichs, W., Schröder, T. and Venghaus, S. (2016), German energy policy and the way to sustainability: Five controversial issues in the debate on the "Energiewende", Energy, 115(Part 3), pp. 1580-1591. https://doi.org/10.1016/j.energy.2016.05.069

Fitjar, R.D. and Rodríguez-Pose, A. (2011), When Local Interaction Does Not Suffice: Sources of Firm Innovation in Urban Norway, Environment and Planning A, 43(6), pp. 1248-1267. https://doi.org/10.4337/9781781002896.00013

Fitjar, R.D. and Rodríguez-Pose, A. (2013), The geographical dimension of innovation collaboration: Networking and innovation in Norway, Urban Studies, 51(12), pp. 2572-2595. https://doi.org/10.1177\%2F0042098013510567

Fitjar, R.D. and Rodríguez-Pose, A. (2016), Nothing is in the Air, Growth and Change, 48(1), pp. 22-39. https://doi.org/10.1111/grow.12161

Flanagan, K., Uyarra, E. and Laranja, M. (2011), Reconceptualising the 'policy mix' for innovation, Research Policy, 40(5), pp. 702-713. https://doi.org/10.1016/j.respol.2011.02.005

Foray, D. (2014a), From smart specialisation to smart specialisation policy, European Journal of Innovation Management, 17(4), pp. 492-507. https://doi.org/10.1108/EJIM-09-2014-0096

Foray, D. (2014b), Smart specialisation, London: Routledge.

Fornahl, D., Hassink, R., Klaerding, C., Mossig, I. and Schroder, H. (2012), From the Old Path of Shipbuilding onto the New Path of Offshore Wind Energy? The Case of Northern Germany, European Planning Studies, 20(5), pp. 835-855. https://doi.org/10.1108/EJIM-09-2014-0096

Frenken, K. and Boschma, R.A. (2007), A theoretical framework for evolutionary economic geography: industrial dynamics and urban growth as a branching process, Journal of Economic Geography, 7(5), pp. 635-649. https://doi.org/10.1093/jeg/lbm018

Frenken, K., Oort, F.V. and Verburg, T. (2007), Related Variety, Unrelated Variety and Regional Economic Growth, Regional Studies, 41(5), pp. 685-697. https://doi.org/10.1080/00343400601120296 
Giuliani, E. (2007), The selective nature of knowledge networks in clusters: evidence from the wine industry, Journal of Economic Geography, 7(2), pp. 139-168. https://doi.org/10.1093/jeg/lbl014

Gkypali, A., Filiou, D. and Tsekouras, K. (2017), R\&D collaborations: Is diversity enhancing innovation performance?, Technological Forecasting and Social Change, 118(Supplement C), pp. 143-152. https://doi.org/10.1016/j.techfore.2017.02.015

Grabher, G. (1993), The embedded firm: On the socio-economics of industrial networks, London: Yale University Press.

Grillitsch, M. and Nilsson, M. (2015), Innovation in peripheral regions: Do collaborations compensate for a lack of local knowledge spillovers?, The Annals of Regional Science, 54(1), pp. 299-321. https://doi.org/10.1007/s00168-014-0655-8

Grillitsch, M. and Sotarauta, M. (2020), Trinity of change agency, regional development paths and opportunity spaces, Progress in Human Geography, 44(4), pp. 704-723. https://doi.org/10.1177\%2F0309132519853870

Grillitsch, M. and Trippl, M. (2016), Innovation Policies and New Regional Growth Paths: A place-based system failure framework, CIRCLE Papers in Innovation Studies, (26), pp. 1-23.

Grillitsch, M., Asheim, B.T. and Trippl, M. (2018), Unrelated knowledge combinations: the unexplored potential for regional industrial path development, Cambridge Journal of Regions, Economy and Society, 11(2), pp. 257-274. https://doi.org/10.1093/cjres/rsy012

Grillitsch, M., Martin, R. and Srholec, M. (2017), Knowledge Base Combinations and Innovation Performance in Swedish Regions, Economic Geography, 93(5), pp. 458479. https://doi.org/10.1080/00130095.2016.1154442

Grimpe, C. and Kaiser, U. (2010), Balancing Internal and External Knowledge Acquisition: The Gains and Pains from R\&D Outsourcing, Journal of Management Studies, 47(8), pp. 1483-1509. https://doi.org/10.1111/j.1467-6486.2010.00946.x

Groenewegen, J. and van der Steen, M. (2007), The Evolutionary Policy Maker, Journal of Economic Issues, 41(2), pp. 351-358. https://doi.org/10.1080/00213624.2007. $\underline{11507021}$

Guerzoni, M. and Raiteri, E. (2015), Demand-side vs. supply-side technology policies: Hidden treatment and new empirical evidence on the policy mix, Research Policy 44(3), pp. 726-747. https://doi.org/10.1016/j.respol.2014.10.009

Hausmann, R. (2016), Economic development and the accumulation of knowhow, Welch Economic Review, 24, pp. 13-16.

Hausmann, R. and Rodrik, D. (2003), Economic development as self-discovery, Journal of Development Economics, 72(2), pp. 603-633. https://doi.org/10.1016/S0304$\underline{3878(03) 00124-X}$

Heggedal, T.-R. (2015), Knowledge spillovers and R\&D subsidies to new, emerging technologies, Economics of Innovation and New Technology, 24(7), pp. 710-733. https://doi.org/10.1080/10438599.2014.983691 
Herrmann, A.M. and Peine, A. (2011), When 'national innovation system' meet 'varieties of capitalism' arguments on labour qualifications: On the skill types and scientific knowledge needed for radical and incremental product innovations, Research Policy 40(5), pp. 687-701. https://doi.org/10.1016/j.respol.2011.02.004

Herstad, S. and Brekke, T. (2012), Globalization, modes of innovation and regional knowledge diffusion infrastructures, European Planning Studies, 20(10), pp. 6031625. https://doi.org/10.1080/09654313.2012.713334

Herstad, S. and Ebersberger, B. (2015), On the link between urban location and the involvement of knowledge intensive business services in collaboration networks, Regional Studies, $\quad 49(7), \quad$ pp. $1160-1175$. https://doi.org/10.1080/00343404.2013.816413

Herstad, S. and Sandven, T. (2017), Towards regional innovaton systems in Norway?, NIFU REPORT, 2017, pp. 1-194.

Herstad, S., Bloch, C., Ebersberger, B. and van De Velde, E. (2010), National innovation policy and global open innovation: Exploring trade-offs, balances and complementarities, Science and Public Policy, 37(2), pp. 113-124. https://doi.org/10.3152/030234210X489590

Herstad, S., Sandven, T. and Ebersberger, B. (2015), Recruitment, knowledge integration and modes of innovation, Research Policy, 44(1), pp. 138-153. https://doi.org/10.1016/j.respol.2014.06.007

Herstad, S.J. (2017), Innovation strategy choices in the urban economy, Urban Studies, 55(6), pp. 1185-1202. https://doi.org/10.1177\%2F0042098017692941

Herstad, S.J. (2018a), Beyond 'related variety': how inflows of skills shape innovativeness in different industries, European Planning Studies, 26(2), pp. 396-420. https://doi.org/10.1080/09654313.2017.1392490

Herstad, S.J. (2018b), Innovation strategy choices in the urban economy, Urban Studies, 55(6), pp. 1185-1202. https://doi.org/10.1177\%2F0042098017692941

Herstad, S.J., Solheim, M.C. and Engen, M. (2019), Learning through urban labour pools: Collected worker experiences and innovation in services, Environment and Planning A, 51(8), pp. 1720-1740. https://doi.org/10.1177\%2F0308518X19865550

Hidalgo, C.A. and Hausmann, R. (2009), The building blocks of economic complexity, Proceedings of the national academy of sciences of the United states, 106(26), pp. 10570-10575. https://doi.org/10.1073/pnas.0900943106

Hidalgo, C.A., Balland, P.-A., Boschma, R., Delgado, M., Feldman, M., Frenken, K., Glaeser, E., He, C., Kogler, D.F., Morrison, A., Neffke, F., Rigby, D., Stern, S., Zheng, S. and Zhu, S. (2018), The Principle of Relatedness, in: International conference on complex systems, pp. 451-457, Springer International Publishing, Cham.

Hidalgo, C.A., Klinger, B., Barbasi, A.L. and Hausmann, R. (2007), The product space conditions the development of nations, Science, 317(5837), pp. 482-487.

Hodgson, G.M. (1999), Economics and utopia, London: Routledge. 
Isaksen, A. and Trippl, M. (2016), Path development in different regional innovation systems, in: Parilli, M., Fitjar, R.D. and Rodríguez-Pose, A.(eds.), Innovation Drivers and Regional Innovation Strategies, New York and London: Routledge, pp. 66-84.

Isaksen, A. and Trippl, M. (2017), Exogenously Led and Policy-Supported New Path Development in Peripheral Regions: Analytical and Synthetic Routes, Economic Geography, 93(5), pp. 436-457. https://doi.org/10.1080/00130095.2016.1154443

Jensen, M.B., Johnson, B., Lorenz, E. and Lundvall, B.A. (2007), Forms of knowledge and modes of innovation, Research Policy, 36, pp. 680-693.

Joas, F., Pahle, M., Flachsland, C. and Joas, A. (2016), Which goals are driving the Energiewende? Making sense of the German Energy Transformation, Energy Policy, 95(Supplement C), pp. 42-51. https://doi.org/10.1016/j.enpol.2016.04.003

Jøranli, I. and Herstad, S.J. (2017), Urban concentration and labour market linkages in the Norwegian ICT services sector, European Planning Studies, 25(10), pp. 1734-1755. https://doi.org/10.1080/09654313.2017.1337726

Klepper, S. (2001), Employee Startups in High-Tech industries, Industrial and Corporate Change, 10(3), pp. 639-674. https://doi.org/10.1093/icc/10.3.639

Klepper, S. (2007), Disagreements, Spinoffs, and the Evolution of Detroit as the Capital of the U.S. Automobile Industry, Management Science, 53(4), pp. 616-631. https://doi.org/10.1287/mnsc. 1060.0683

Laffont, J.-J. and Tirole, J. (1991), The politics of government decision-making: A theory of regulatory capture, The quarterly journal of economics, 106(4), pp. 1089-1127. https://doi.org/10.2307/2937958

Landini, F. and Malerba, F. (2017), Public policy and catching up by developing countries in global industries: a simulation model, Cambridge Journal of Economics, 41(3), pp. 927-960. https://doi.org/10.1093/cje/bex017

Lauridsen, L.S. (2018), New economic globalization, new industrial policy and late development in the 21st century: A critical analytical review, Development Policy Review, 36(3), pp. 329-346. https://doi.org/10.1111/dpr.12299

Laursen, K., Masciarelli, F. and Prencipe, A. (2012), Trapped or spurred by the home region? The effects of potential social capital on involvement in foreign markets for goods and technology, Journal of International Business Studies, 43(9), pp. 783-807. https://doi.org/10.1057/jibs.2012.27

MacKinnon, D. (2012), Beyond strategic coupling: reassessing the firm-region nexus in global production networks, Journal of Economic Geography, 12(1), pp. 227-245. https://doi.org/10.1093/jeg/lbr009

March, J.G. (1991), Exploration and exploitation in organizational learning, Organization Science, 2(1), pp. 71-87. https://doi.org/10.1287/orsc.2.1.71

Martin, R. and Simmie, J. (2008), Path dependence and local innovation systems in cityregions, Innovation, 10(2-3), pp. 183-196. https://doi.org/10.5172/impp.453.10.2$\underline{3.183}$ 
Martin, R. and Sunley, P. (2006), Path dependence and regional economic evolution, Journal of Economic Geography, 6(4), pp. 395-437. https://doi.org/10.1093/jeg/lbl012

Mazzucato, M. (2013), The Entrepreneurial State: Debunking Public vs. Private Sector Myths, London: Anthem Press.

Mazzucato, M. (2016), From market fixing to market-creating: a new framework for innovation policy, Industry and Innovation, 23(2), pp. 140-156. https://doi.org/10.1080/13662716.2016.1146124

Mazzucato, M. and Semieniuk, G. (2017), Public financing of innovation: new questions, Oxford Review of Economic Policy, 33(1), pp. 24-48. https://doi.org/10.1093/oxrep/grw036

McCann, P. and Ortega-Argilés, R. (2013), Modern regional innovation policy, Cambridge Journal of Regions, Economy and Society, 6(2), pp. 187-216. https://doi.org/10.1093/cjres/rst007

McCann, P. and Ortega-Argilés, R. (2014), Smart specialisation in European regions: issues of strategy, institutions and implementation, European Journal of Innovation Management, 17(4), pp. 409-427. https://doi.org/10.1108/EJIM-05-2014-0052

Mewes, L. and Broekel, T. (2020), Technological complexity and economic growth of regions, Research Policy. https://doi.org/10.1016/j.respol.2020.104156

Meyer, K. and Sinani, E. (2009), Where and When Does Foreign Direct Investment Generate Positive Spillovers? A Meta Analysis, Journal of International Business Studies, 40(7), pp. 1075-1094. https://doi.org/10.1057/jibs.2008.111

Morgan, K. (2017), Nurturing novelty: Regional innovation policy in the age of smart specialisation, Environment and Planning C: Politics and Space, 35(4), pp. 569583. https://doi.org/10.1177\%2F0263774X16645106

Narula, R. (2002), Innovation systems and 'intertia' in R\&D location: Norwegian firms and the role of systemic lock-in, Research Policy, 31(5), pp. 795-816. https://doi.org/10.1016/S0048-7333(01)00148-2

Neffke, F. and Henning, M. (2013), Skill relatedness and firm diversification, Strategic Management Journal, 34(3), pp. 297-316. https://doi.org/10.1002/smj.2014

Neffke, F., Henning, M. and Boschma, R. (2011), How do regions diversity over time? Industry relatedness and the development of new growth paths in regions, Economic Geography, 87(3), pp. 237-265.

Nelson, R. and Winter, S. (1982), An evolutionary theory of economic change, Cambridge, MA: Harvard University Press.

Nelson, R.R. and Winter, S.G. (2002), Evolutionary Theorizing in Economics, The Journal of Economic Perspectives, 16(2), pp. 23-46. https://doi.org/10.1257/0895330027247

OECD (2013), Review of Innovation Policy: Sweden 2012, Paris: OECD publishing.

Peneder, M. (2017), Competitiveness and industrial policy: from rationalities of failure towards the ability to evolve, Cambridge Journal of Economics, 41(3), pp. 829-858. https://doi.org/10.1093/cje/bew025 
Pinheiro, F., Alshamsi, A., Hartmann, D., Boschma, R. and Hidalgo, C.A. (2018), Shooting High or Low: Do Countries Benefit from Entering Unrelated Activities?, Papers in Evolutionairy Economic Geography, 1807.

Power, D. and Lundmark, M. (2004), Working through knowledge pools: labour market dynamics, the transference of knowledge and ideas, and industrial clusters, Urban Studies, 41(5-6), pp. 1025-1044. https://doi.org/10.1080\%2F00420980410001675850

Reichardt, K. and Rogge, K. (2016), How the policy mix impacts innovation: Findings from company case studies on offshore wind in Germany, Environmental Innovation and Societal Transitions, 18(Supplement $\quad$ C), $\quad$ pp. 62-81. https://doi.org/10.1016/j.eist.2015.08.001

Rodríguez-Pose, A. and Garcilazo, E. (2015), Quality of Government and the Returns of Investment: Examining the Impact of Cohesion Expenditure in European Regions, Regional Studies, $49(8), \quad$ pp. $1274-1290$. https://doi.org/10.1080/00343404.2015.1007933

Rogge, K.S. and Reichardt, K. (2016), Policy mixes for sustainability transitions: An extended concept and framework for analysis, Research Policy, 45(8), pp. 16201635. https://doi.org/10.1016/j.respol.2016.04.004

Saviotti, P.P. and Frenken, K. (2008), Export variety and the economic performance of countries, Journal of Evolutionary Economics, 18(2), pp. 201-218. https://doi.org/10.1007/s00191-007-0081-5

Simmie, J. (2012), Path Dependence and New Technological Path Creation in the Danish Wind Power Industry, European Planning Studies, 20(5), pp. 753-772. https://doi.org/10.1080/09654313.2012.667924

Simmie, J., Sternberg, R. and Carpenter, J. (2014), New technological path creation: evidence from the British and German wind energy industries, Journal of Evolutionary Economics, 24(4), pp. 875-904. https://doi.org/10.1007/s00191-014-0354-8

Smarzynska Javorcik, B. (2004), Does foreign direct investment increase the productivity of domestic firms? In search of spillovers through backward linkages, American Economic Review, 94(3), pp. 605-627. https://doi.org/10.1257/0002828041464605

Solheim, M.C.W. and Herstad, S.J. (2018), The differentiated effects of human resource diversity on corporate innovation, International Journal of Innovation and Technology Management, $15(05), \quad$ p. 1850046. https://doi.org/10.1142/S0219877018500463

Solheim, M.C.W., Boschma, R. and Herstad, S. (2018), Contextualizing the nexus between workforce diversity and innovation novelty, Paper presented at the 2018 Geography of innovation conference.

Solheim, M.C.W., Boschma, R. and Herstad, S.J. (2020), Collected worker experiences and the novelty content of innovation, Research Policy, 49(1), p. 103856. https://doi.org/10.1016/j.respol.2019.103856

Teirlinck, P., Dumont, M. and Spithoven, A. (2010), Corporate decision-making in R\&D outsourcing and the impact on internal R\&D employment intensity, Industrial and Corporate Change, 19(6), pp. 1741-1768. https://doi.org/10.1093/icc/dtq038 
The Expert Group (2006), Creating an innovative Europe, Brussels: European Communities.

Timmermans, B. and Boschma, R. (2014), The effect of intra- and inter-regional labour mobility on plant performance in Denmark: the significance of related labour inflows, Journal of Economic Geography, 14(2), pp. 289-311. https://doi.org/10.1093/jeg/lbs059

UNCTAD (2018), World Investment Report 2018: Investment and new industrial policies, Geneva, United Nations (retrieved from https://unctad.org/webflyer/worldinvestment-report-2018).

Wade, R.H. (2017), The American paradox: ideology of free markets and the hidden practice of directional thrust, Cambridge Journal of Economics, 41(3), pp. 859-880. https://doi.org/10.1093/cje/bew064

Weber, K.M. and Rohracher, H. (2012), Legitimizing research, technology and innovation policies for transformative change Combining insights from innovation systems and multi-level perspective in a comprehensive 'failures' framework, Research Policy, 41(6), pp. 1037-1047. https://doi.org/10.1016/j.respol.2011.10.015

Xiao, J., Boschma, R. and Andersson, M. (2018), Industrial Diversification in Europe: The Differentiated Role of Relatedness, Economic Geography, 94(5), pp. 514-549. https://doi.org/10.1080/00130095.2018.1444989

Zhu, S., He, C. and Zhou, Y. (2017), How to jump further and catch up? Path-breaking in an uneven industry space, Journal of Economic Geography, 17(3), pp. 521-545. https://doi.org/10.1093/jeg/lbw047

Zukauskaite, E. and Moodysson, J. (2016), Multiple paths of development: knowledge bases and institutional characteristics of the Swedish food sector, European Planning Studies, 24(3), pp. 589-606. https://doi.org/10.1080/09654313.2015.1092502 